\title{
Trade, resources and inequality in Latin America
}

\section{Juan Luis Londoño}

Minister of Labour and

Minister of Health,

Colombia

jlondoño@cable.net.co
This article uses international databases to empirically

estimate the links between inequality and trade. It looks first

at the links between trade openness, income distribution and relative factor abundance. Next, it uses the results obtained to analyse the changing relative resource endowment of Latin America and its distributive consequences. The main conclusion is that, behind the persistent high level of inequality in the region, substantive changes have been taking place. The Latin American pattern of relative resource abundance has changed with the inroads made by Asia, China and Russia into global trade, which have reduced Latin America's relative abundance of unskilled labour and resources, respectively. The developed countries have expanded their endowment of fixed capital, while Latin America has not been able to accumulate the physical and human capital that would make a stronger emphasis on external trade compatible with greater income equity. 
A businessman and an economist were hunting in the jungle. Suddenly, an enormous tiger loomed up some 200 metres away. The economist warned the businessman of the size and characteristics of the risk. The businessman did not waste a minute, and while listening to the economist he started putting on his tennis shoes. Surprised, the economist told him to forget his tennis shoes and start running, as the tiger was coming straight towards them and was going to devour them. The businessman calmly replied, however: "My problem is not running faster than the tiger: it's running faster than you".

\section{I}

\section{Chi va piano non va lontano*}

After the debt crisis of the 1980s, Latin America made a huge effort in the following decade to achieve structural adjustment and trade openness. An enormous, sustained attempt was made to do away with restrictions on foreign trade, and the current levels of tariff and para-tariff protection are lower than at any time during the twentieth century, while the intensity of foreign trade is correspondingly higher.

However, this opening-up occurred in the context of highly unequal societies. Latin America has long been the region of the world with the highest income inequality. Many analysts attribute this inequality precisely to foreign trade policy in the post-war period: an import substitution model which under-utilized the resources that were the most plentiful -labour and landand conversely generated high capital inflows. For these analysts, it seemed natural to expect that more intense and freer foreign trade would reduce income inequalities. Since the 1980s, however, there has not been greater progress in terms of distribution: ${ }^{1}$ on the contrary, trade openness has been accompanied by even more unequal income distribution. Indeed, by the end of the 1990s, the share of the $5 \%$ richest segment of

\footnotetext{
* "Slowly but not so surely".

$\square$ This article is based on a joint study conducted by the author with Antonio Spilimbergo and Miguel Székely at the InterAmerican Development Bank (IDB), which was published under joint authorship in the Journal of Economic Development with the title "Income distribution, factor endowments and trade openness". It also draws on and supplements presentations made at the Conference of the National Bureau of Economic Research, Inc. (NBER) on income distribution, at the Meeting of the Latin American and Caribbean Economics Association (LACEA) and at the annual conference of the World Bank on development economics, but I bear sole responsibility for the views expressed herein.

${ }^{1}$ See Londoño and Székely (1998), ECLAC (2000) and Morley (2001).
}

the population in national income had increased, while that of the $50 \%$ poorest had dwindled to less than $10 \%$ of the total.

It is therefore hardly surprising that the pendulum of public opinion has swung significantly in the opposite direction, and many analysts today attribute the worsening distributive situation to the openness of economies or see it as a price economies have to pay in order to recover their competitiveness. ${ }^{2}$ Nevertheless, little evidence has so far been presented of a solid link between openness and inequality.

This article seeks precisely to use the valuable international databases currently available on the four last decades to estimate empirically the connection between inequality and trade and thus shed more light on the case of Latin America. Following a brief introduction (section I), an empirical study is presented for a large group of countries on the links between trade openness, income distribution and relative resource availability (section II), and the results are then used to analyse the changing relative resource endowment of Latin America and its effect on income distribution (section III).

The main conclusion is that behind the persistently high inequality in Latin America, substantive changes have taken place. The traditional Latin American pattern of relative resource abundance was broken by the entry of Asia and Eastern Europe into world trade. Up to the 1970 s, the growing relative abundance of land and

\footnotetext{
2 The first to draw attention to this negative relationship were Bulmer-Thomas (1996) and Berry (ed., 1998). Edwards (1997), however, pointed out that there was no empirical evidence of such a systematic link. Recent studies -IDB (2000), Morley (2001), Stallings and Peres (2000) and Ganuza and others (eds., 2001)find that this link differs considerably from one country to another.
} 
unskilled labour led to a combination of greater trade and greater income inequality in Latin America. But this relative abundance changed with the entry of two other regions into the world trade arena. With the entry of Asia, the abundance of unskilled labour in Latin America diminished in relative terms, and when the former Soviet Union linked up with the world economy, the region's previous relative natural resource abundance started to wane too, while at the same time Latin America did not manage to accumulate the new resources -physical and human capital- which would make a stronger emphasis on external trade compatible with greater income equality.

Thus, although income inequality remains high, the factors underlying this inequality have changed. It is no longer due to the abundance of land and labour, but rather now to the relative lack of physical and human capital. These two factors are those which, in other parts of the world and at other times, have generated greater economic growth combined with greater trade intensity and greater income equality.

The slow rate of capital accumulation (chi va piano...) has proven very costly from the social point of view. In the new century, progress in terms of distribution and trade (going lontano) will depend on boosting investment not only with respect to historical patterns but also compared with the rest of the world. In order to overcome its isolation, inequity and poverty, Latin America must protect investment in businesses and homes and do so fast.

\section{II}

\section{Trade openness and income distribution}

\section{Trade, regions and resources}

One of the most notable aspects of world development in the last two decades was the growing intensity of international trade. Trade has grown faster than income in almost all economies, including those of Latin America, but in this region the changes in trade intensity have been less significant by world standards and have also been slower than expected. For this reason, their link with distributive changes is not so simple.

Between the 1970s and the 1990s, Latin America saw its trade flows expand considerably as the share of exports in GDP rose from $65 \%$ to $70 \%$. This increase in trade is small, however, compared with that of other regions. Figure 1 shows that the recent increase in Latin American trade has not been faster than it was in the 1970s or faster than the average for the countries of the world in the 1990s.

In the past, the study of the links between income inequality and trade openness was focused on a few countries and on periods of time when changes in trade coincided with the availability of income distribution data (Spilimbergo, Londoño and Székely, 1999). This was done ${ }^{3}$ in an effort to isolate the effect of trade

${ }^{3}$ See, for example, Morley (2000), Stallings and Peres (2000) and Ganuza (2001).

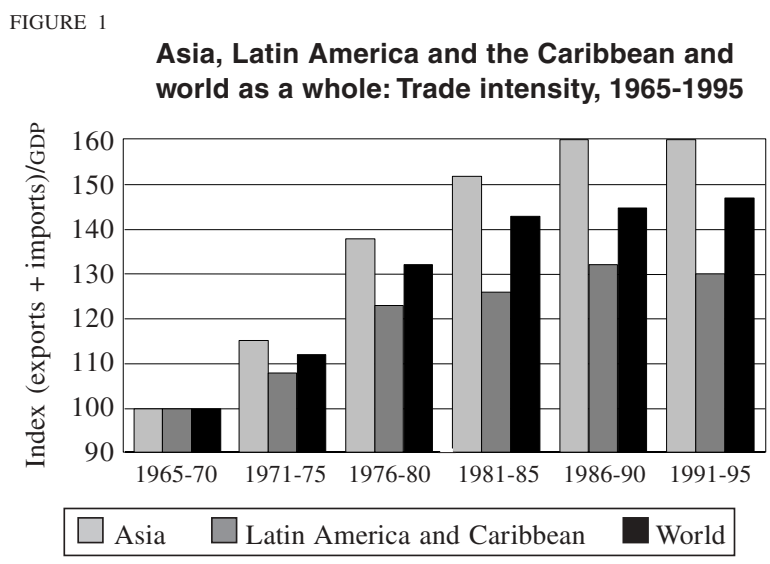

Source: See footnote 5 on page 28 .

openness from that of other macroeconomic events, such as liberalization of the capital account and the financial system, or fiscal adjustments and variations in the rate of exchange, which have undoubtedly had major short-term effects, although whether these have been positive or negative is still subject to discussion.

Today, it is possible to use a broader set of countries and periods of time. In the Office of the Chief Economist of IDB we compiled an impressive database on income distribution, trade, education, capital and 
the labour force, ${ }^{4}$ which has made possible a maximum of almost 3,000 annual observations of countries at all levels of development for the period 1960-1995. ${ }^{5}$

What we presented with Spilimbergo and Székely in 1999 was a formal theoretical model derived from the model for more than two factors and $n$ countries presented by Leamer (1987), the general lines of which are given in the appendix. Using an earlier version of this database, we explored the relationship between trade intensity and income inequality and found, after many robustness tests, that there is no obvious direct link between the two. In this article we extend this study with the help of new econometric procedures. Table 1 shows the main results.
There is no close direct relationship between trade and inequality. According to equation [1a], the differences in trade intensity of the different economies in the world only explain an insignificant portion -less than one-fifth of $1 \%-$ of the distributive variance.

The connection between inequality and the income level, in line with the tradition of Kuznets, is somewhat higher than the connection with trade, as it explains 9\% of the variance (equation [2a]). The size and sign of the coefficients are consistent with Kuznets's wellknown inverted $U$ theory, with the breaking point coming after a per capita income of US\$ 1,800 , using the 1985 purchasing power parity (a level that Latin America achieved in the late 1950s). In the database

TABLE 1

Developing countries: Trade intensity and income distribution ${ }^{a}$

\begin{tabular}{|c|c|c|c|c|c|c|c|c|c|c|}
\hline Equations & [1a] & {$[1 b]$} & [1c] & [2a] & {$[2 \mathrm{~b}]$} & [2c] & {$[3 a]$} & {$[3 b]$} & [3c] & [4] \\
\hline Constant & $\begin{array}{c}33.9 \\
(57.6)\end{array}$ & $\begin{array}{l}35.6 \\
(66)\end{array}$ & $\begin{array}{c}39.5 \\
(21.3)\end{array}$ & $\begin{array}{l}-49.9 \\
(1.6)\end{array}$ & $\begin{array}{l}8.82 \\
(0.4)\end{array}$ & $\begin{array}{r}-63.5 \\
(0.8)\end{array}$ & $\begin{array}{l}-26.5 \\
(0.8)\end{array}$ & $\begin{array}{c}-12.6 \\
(0.6)\end{array}$ & $\begin{array}{r}-61.5 \\
(0.8)\end{array}$ & $\begin{array}{l}-55.7 \\
(2.1)\end{array}$ \\
\hline Exports + imports & $\begin{array}{l}0.02 \\
(2.4)\end{array}$ & $\begin{array}{l}0.01 \\
(1.2)\end{array}$ & $\begin{array}{l}0.02 \\
(0.7)\end{array}$ & & & & $\begin{array}{l}0.02 \\
(2.5)\end{array}$ & $\begin{array}{l}0.01 \\
(1.0)\end{array}$ & $\begin{array}{l}0.04 \\
(1.8)\end{array}$ & $\begin{array}{l}-0.01 \\
(0.2)\end{array}$ \\
\hline $\mathrm{y}$ & & & & $\begin{array}{l}23.5 \\
(3.0)\end{array}$ & $\begin{array}{c}6.5 \\
(1.3)\end{array}$ & $\begin{array}{l}30.2 \\
(1.5)\end{array}$ & $\begin{array}{l}17.6 \\
(2.2)\end{array}$ & $\begin{array}{c}5.8 \\
(1.2)\end{array}$ & $\begin{array}{l}29.5 \\
(1.5)\end{array}$ & $\begin{array}{l}22.3 \\
(3.3)\end{array}$ \\
\hline$y^{2}$ & & & & $\begin{array}{l}-1.57 \\
(3.3)\end{array}$ & $\begin{array}{l}-0.4 \\
(1.3)\end{array}$ & $\begin{array}{l}-2.1 \\
(1.7)\end{array}$ & $\begin{array}{l}-1.21 \\
(2.5)\end{array}$ & $\begin{array}{l}-0.4 \\
(1.2)\end{array}$ & $\begin{array}{l}-2.1 \\
(1.7)\end{array}$ & $\begin{array}{l}-1.3 \\
(3.2)\end{array}$ \\
\hline Asia & & & & & & & & & & $\begin{array}{c}4.8 \\
(3.4)\end{array}$ \\
\hline Eastern Europe & & & & & & & & & & $\begin{array}{l}-6.4 \\
(6.1)\end{array}$ \\
\hline Middle East & & & & & & & & & & $\begin{array}{l}10.6 \\
(6.8)\end{array}$ \\
\hline Latin America and Caribbean & & & & & & & & & & $\begin{array}{c}18.6 \\
(18.0)\end{array}$ \\
\hline Land-rich countries & & & & & & & & & & $\begin{array}{c}3.8 \\
(4.3)\end{array}$ \\
\hline East Asia & & & & & & & & & & $\begin{array}{c}5.6 \\
(4.6)\end{array}$ \\
\hline Africa & & & & & & & & & & $\begin{array}{c}5.9 \\
(9.3)\end{array}$ \\
\hline Method & Huber & $\begin{array}{c}\text { Changes } \\
\text { within } \\
\text { countries }\end{array}$ & $\begin{array}{c}\text { Differences } \\
\text { between } \\
\text { countries }\end{array}$ & Huber & $\begin{array}{c}\text { Changes } \\
\text { within } \\
\text { countries }\end{array}$ & $\begin{array}{c}\text { Differences } \\
\text { between } \\
\text { countries }\end{array}$ & Huber & $\begin{array}{l}\text { Changes } \\
\text { within } \\
\text { countries }\end{array}$ & $\begin{array}{c}\text { Differences } \\
\text { between } \\
\text { countries }\end{array}$ & Huber \\
\hline $\mathrm{R}^{2}$ & 0.002 & 0.003 & 0.006 & 0.09 & 0.001 & 0.09 & 0.09 & 0.006 & 0.17 & 0.64 \\
\hline $\begin{array}{l}\text { Differences } \\
\text { between countries } \\
\text { Changes within countries }\end{array}$ & & & & & $\begin{array}{l}0.022 \\
0.004\end{array}$ & $\begin{array}{c}0.15 \\
0.0003\end{array}$ & & & & \\
\hline Number of observations & 565 & 565 & 565 & 565 & 565 & 565 & 565 & 565 & 565 & 565 \\
\hline
\end{tabular}

Source: See footnote 5 .

${ }^{\mathrm{a}} t$ statistics are shown in brackets.

${ }^{4}$ See Spilimbergo, Londoño and Székely (1999).

${ }^{5}$ The income distribution data are taken from Deininger and Squire (1996). The capital data come from Serageldin (1996) and the Penn World Tables (1995). The trade figures were drawn from the World

Trade Organization (wTO) databases. The data on education were supplied by Barro and Lee (2000), and the information on the labour force came from the records of the International Labour Organisation (ILO). 
used, however, which covers a period of 35 years, the Kuznets regularity reflects differences between countries rather than changes within countries over time. The data panel technique makes it possible to distinguish between the variance attributable to changes in income in each country and that attributable to other unidentified elements in each country, which may include structural variables (such as their type of specialization or the degree of segmentation of their factor markets) or institutional variables (such as whether they underwent early or late industrialization). Equations [2b] and [2c] confirm that the dominant component is not that of the changes within countries. The link between trade intensity and inequality, once income is controlled out, also reflects differences between countries rather than the changes within each of them over time (equations [3b] and [3c]).

Geographical location is the element which contributes the most to inequality between countries. As shown in equation [4], it accounts for four times as much variance as the other variables. After controlling for income and trade intensity, income inequality is greater in Latin America and Africa and lower in Asia and in countries that have recently switched to the market economy, than in Europe. Regional differences account for almost two-thirds of the variance in income distribution and eliminate the statistical significance of the relationship between trade intensity and inequality.

The differences between regions are an important clue for shedding light on the possible channels of connection between trade and inequality. Those who have compared Latin America only with East Asia have suggested an apparently positive relationship between trade and equality, with these two regions as extreme points. But the simple linear relationship disappears if countries from other regions in the world are included. The least open regions are not always the most unequal, as shown in figure 2: the countries of South Asia or the frontier developed countries have less inequality and openness than the world average. Likewise, not all open regions have less inequality: Africa is open but there is high inequality.

\section{Trade and resource availability}

What are the factors behind the close link between regional geography and trade intensity? Leaving aside consideration of the historical diversities of specialization patterns, styles of economic policy or macroeconomic upheavals, the most natural tendency is to relate geographic differences between countries

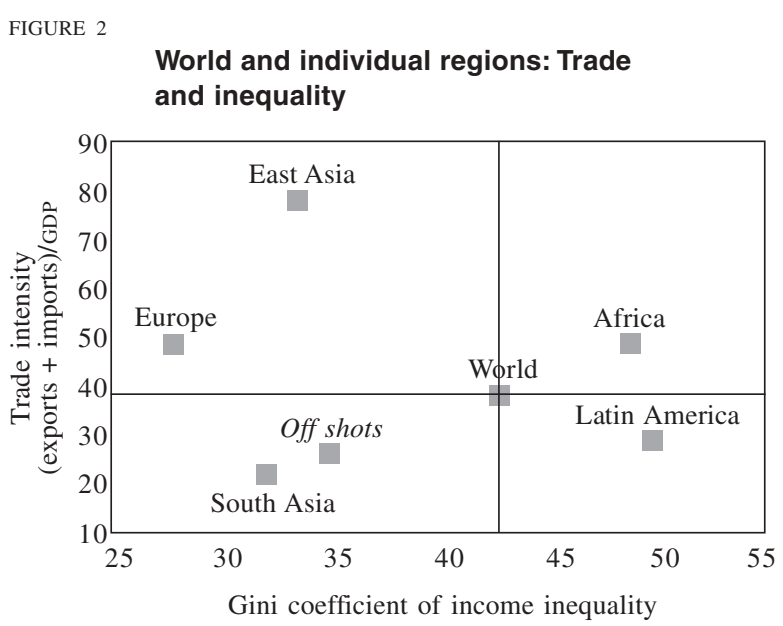

Source: See footnote 5 on page 28 .

to their resource endowment. A country's economic geography affects its trade opportunities, as various authors $^{6}$ have pointed out. The smaller countries in terms of population and area, as well as countries that are physically closer to others, need more trade to function as an economy. The negative empirical link between a country's size, distance from markets and trade intensity is confirmed by the panel of almost 3,000 observations (first section of table 2). This dependency of trade on economic geography proves even greater when we control for the effects of the reduction in transport costs (equation [2]). ${ }^{7}$

Trade intensity is closely linked to the availability of productive resources in the different countries. According to the Ricardian comparative advantage tradition, countries trade more when they have resources that are different from the rest of the world. The trade intensity of each country would therefore be proportional to its relative resource abundance.

The wealth of information by country which is available allows us to measure the relative resource abundance of each country. This relative abundance for country $i$ in period $t$ is measured as the quotient of the resource abundance in each country and the average for the rest of the world (in logarithms). For example, if the average number of years of education in a country

\footnotetext{
6 See in particular Leamer (1987); Krugman (1992); Williamson (1996); Sachs (2002) and Acemoglu, Johnson and Robinson (2001). ${ }^{7}$ We also carried out an experiment in which the effects of world trade were captured with specific dummy variables for the different five-year periods. The coefficients were similar to those indicated here.
} 
is eight and in the rest of the world it is six, then that country has abundant human capital. A measure that magnifies the difference between countries is the square of this quotient, which we term relative availability. ${ }^{8}$ Finally, in order to obtain a synthetic indicator of the degree of each country's factor specificity, we calculate the aggregate discrepancy of resources as the simple sum of the relative availabilities of each factor in each year. With these three indicators, it is possible to estimate the econometric relationships between geography, resources and trade intensity. The results are presented in table 2 .

The differences in trade intensity are explained by geographical variables and by disparities in the relative abundance of resources among countries: $\mathrm{R}^{2}$ of 0.73 in equation [3] compared with 0.35 in equation [1]. Trade intensity is affected by the relative abundance of each one of the four resources: land, labour, human capital and capital (equation [3]) and by the discrepancies in the set of factors (equation [4]). The differences in abundance of the primary resources of land and unskilled labour are statistically very significant (equations [6] to [8]) and, in accordance with the magnitude of the regression coefficients, the greatest quantitative impact comes from the differences in accumulation of physical capital and human capital. Thus, trade varies significantly with changes in the relative abundance of primary resources or accumulated capital. These differences in resources are precisely those that underlie the regional differences in trade intensity, ${ }^{9}$ since when they are included the explanatory power of the regional dummy variables disappears.

TABLE 2

Trade, geography and resource availability

(Dependent variable: trade intensity)

\begin{tabular}{|c|c|c|c|c|c|c|c|c|}
\hline \multirow[b]{2}{*}{ EQUATIONS } & \multicolumn{3}{|c|}{ Effect of factor abundance } & \multicolumn{5}{|c|}{ Effect of factor availability } \\
\hline & [1] & [2] & [3] & [4] & {$[5]$} & [6] & [7] & {$[8]$} \\
\hline Constant & $\begin{array}{c}155 \\
(29.4)\end{array}$ & $\begin{array}{l}-1163 \\
(13.5)\end{array}$ & $\begin{array}{c}-1918 \\
(10.5)\end{array}$ & $\begin{array}{r}-1765 \\
(10.3)\end{array}$ & $\begin{array}{c}-1155 \\
(3.6)\end{array}$ & $\begin{array}{r}-1512 \\
(11.6)\end{array}$ & $\begin{array}{r}-1683 \\
(10.3)\end{array}$ & $\begin{array}{c}-1872 \\
(10.8)\end{array}$ \\
\hline $\ln$ area & $\begin{array}{c}-6.0 \\
(23.3)\end{array}$ & $\begin{array}{c}-5.4 \\
(21.9)\end{array}$ & $\begin{array}{c}-6.4 \\
(11.2)\end{array}$ & $\begin{array}{c}-7.3 \\
(15.0)\end{array}$ & $\begin{array}{c}-5.9 \\
(23.2)\end{array}$ & $\begin{array}{c}-5.7 \\
(14.4)\end{array}$ & $\begin{array}{c}-6.5 \\
(14.2)\end{array}$ & $\begin{array}{c}-6.8 \\
(14.9)\end{array}$ \\
\hline ln size & $\begin{array}{c}-2.9 \\
(10.0)\end{array}$ & $\begin{array}{c}-4.1 \\
(14.3)\end{array}$ & $\begin{array}{c}-7.2 \\
(10.4)\end{array}$ & $\begin{array}{l}-5.1 \\
(8.9)\end{array}$ & $\begin{array}{c}-3.6 \\
(12.5)\end{array}$ & $\begin{array}{c}-5.6 \\
(10.3)\end{array}$ & $\begin{array}{c}-6.6 \\
(11.0)\end{array}$ & $\begin{array}{c}-6.8 \\
(11.4)\end{array}$ \\
\hline In distance & $\begin{array}{l}-12.2 \\
(12.6)\end{array}$ & $\begin{array}{l}-13.9 \\
(15.2)\end{array}$ & $\begin{array}{l}-15.6 \\
(9.9)\end{array}$ & $\begin{array}{l}-16.4 \\
(12.6)\end{array}$ & $\begin{array}{l}-15.0 \\
(16.5)\end{array}$ & $\begin{array}{l}-16.6 \\
(14.1)\end{array}$ & $\begin{array}{l}-14.6 \\
(10.1)\end{array}$ & $\begin{array}{l}-15.1 \\
(10.5)\end{array}$ \\
\hline Time & & $\begin{array}{c}0.7 \\
(15.3)\end{array}$ & $\begin{array}{c}1.1 \\
(11.6)\end{array}$ & $\begin{array}{c}1.0 \\
(11.5)\end{array}$ & $\begin{array}{c}0.7 \\
(15.4)\end{array}$ & $\begin{array}{c}0.9 \\
(12.9)\end{array}$ & $\begin{array}{c}1.0 \\
(11.5)\end{array}$ & $\begin{array}{c}1.1 \\
(12.0)\end{array}$ \\
\hline Land & & & $\begin{array}{c}0.039 \\
(2.5)\end{array}$ & & $\begin{array}{c}1.3 \\
(14.7)\end{array}$ & $\begin{array}{c}1.3 \\
(6.4)\end{array}$ & $\begin{array}{c}2.6 \\
(5.3)\end{array}$ & $\begin{array}{c}2.5 \\
(5.1)\end{array}$ \\
\hline Human capital & & & $\begin{array}{c}0.234 \\
(5.8)\end{array}$ & & & $\begin{array}{l}14.5 \\
(5.3)\end{array}$ & $\begin{array}{l}16.1 \\
(5.6)\end{array}$ & $\begin{array}{l}19.0 \\
(6.2)\end{array}$ \\
\hline Capital & & & $\begin{array}{c}0.035 \\
(1.2)\end{array}$ & & & & $\begin{array}{c}5.1 \\
(3.5)\end{array}$ & $\begin{array}{c}5.5 \\
(3.8)\end{array}$ \\
\hline Labour & & & $\begin{array}{c}0.025 \\
(1.1)\end{array}$ & & & & & $\begin{array}{c}1.6 \\
(1.6)\end{array}$ \\
\hline Aggregate discrepancy & & & & $\begin{array}{c}3.4 \\
(8.3)\end{array}$ & & & & \\
\hline Adjusted $\mathrm{R}^{2}$ & 0.35 & 0.37 & 0.73 & 0.71 & 0.40 & 0.59 & 0.71 & 0.72 \\
\hline F-test & 460 & 440 & 177 & 243 & 382 & 233 & 201 & 188 \\
\hline Number of observations & 2930 & 2930 & 436 & 436 & 2899 & 676 & 440 & 436 \\
\hline Method & Huber & Huber & Huber & Huber & Huber & Huber & Huber & Huber \\
\hline
\end{tabular}

Source: See footnote 5 .

\footnotetext{
${ }^{8}$ The abundance of factors in equation [3] is measured as the logarithm of $f i / F w$, while the discrepancy of factors is measured as $(f i / F w)^{2}$. The discrepancy is measured as the sum of all the (Fi/ $F w)^{2}$, where $F i$ is factor availability in country $i$ and $F w$ is the availability of that factor in the world on average.
}

\footnotetext{
${ }^{9}$ The regional dummy variables, when added to equation [8] in table 2, appear statistically significant but add very little to the explanation of the variance. This suggests that factor endowments account for a very significant proportion of regional differences.
} 


\section{Income distribution and resource abundance}

The resource endowment in each country affects the intensity of its trade and also the manner in which the owners of those resources are remunerated. Spilimbergo, Londoño and Székely (1999) formally derived the conclusion that, in a closed economy, factor remuneration depends on the absolute supply of factors. But in an open economy, factor remunerations depend on the relative supply of factors compared with the rest of the world, ${ }^{10}$ and, in view of the ownership structure, factor remunerations are transmitted to personal income distribution. The robustness of these links is measured in table 3 .

The differences in relative abundance of resources account for $27 \%$ of the variance in income distribution between countries (equation [1]), which is three times more than is explained by the level of income in table 1 . When we control for resource density (equation [2]), the classic inverted $U$ shape of the Kuznets equation is maintained.

Greater abundance of land is associated with higher income inequality, which reflects the higher concentration of ownership existing in economies with more land (Engerman and Sokoloff, 1997). Greater abundance of human capital, in contrast, is associated with less income inequality, ${ }^{11}$ since there is a ceiling on the number of years of education that each person can have.

Abundance of unskilled labour and physical capital would apparently seem to have an ambiguous effect on distribution, as shown in equations [1], [2], [3] and [4a]. Once we control for the effects of other structural and institutional factors through fixed-effect models,

TABLE 3

Factor intensity, trade and income distribution

(Dependent variable: Gini coefficient)

\begin{tabular}{|c|c|c|c|c|c|c|c|}
\hline Equations & {$[1]$} & [2] & [3] & {$[4 \mathrm{a}]$} & {$[4 \mathrm{~b}]$} & [5] & {$[6]$} \\
\hline Constant & $\begin{array}{c}45.5 \\
(10.6)\end{array}$ & $\begin{array}{c}-130.9 \\
(3.0)\end{array}$ & $\begin{array}{c}-104.0 \\
(2.4)\end{array}$ & $\begin{array}{c}-104.0 \\
(0.8)\end{array}$ & $\begin{array}{c}-90.1 \\
(2.6)\end{array}$ & $\begin{array}{r}-81.7 \\
(2.3)\end{array}$ & $\begin{array}{c}-124.1 \\
(3.2)\end{array}$ \\
\hline Exports + imports & & & $\begin{array}{l}0.03 \\
(2.5)\end{array}$ & & & & \\
\hline Openness & & & & & & $\begin{array}{l}0.26 \\
(1.2)\end{array}$ & $\begin{array}{r}-0.21 \\
(1.2)\end{array}$ \\
\hline Land & $\begin{array}{c}0.9 \\
(3.3)\end{array}$ & $\begin{array}{c}1.3 \\
(4.7)\end{array}$ & $\begin{array}{c}1.4 \\
(4.7)\end{array}$ & $\begin{array}{c}1.1 \\
(1.6)\end{array}$ & $\begin{array}{c}2.1 \\
(1.1)\end{array}$ & $\begin{array}{c}1.9 \\
(1.2)\end{array}$ & $\begin{array}{c}1.4 \\
(3.6)\end{array}$ \\
\hline Labour & $\begin{array}{c}1.2 \\
(2.8)\end{array}$ & $\begin{array}{c}0.7 \\
(1.5)\end{array}$ & $\begin{array}{c}0.7 \\
(1.6)\end{array}$ & $\begin{array}{c}1.5 \\
(1.2)\end{array}$ & $\begin{array}{l}-1.0 \\
(2.1)\end{array}$ & $\begin{array}{l}-1.0 \\
(2.1)\end{array}$ & $\begin{array}{l}-0.9 \\
(2.8)\end{array}$ \\
\hline Physical capital & $\begin{array}{l}-0.1 \\
(0.1)\end{array}$ & $\begin{array}{c}1.9 \\
(1.6)\end{array}$ & $\begin{array}{c}1.5 \\
(1.3)\end{array}$ & $\begin{array}{c}1.3 \\
(0.5)\end{array}$ & $\begin{array}{l}-2.9 \\
(2.4)\end{array}$ & $\begin{array}{l}-2.4 \\
(1.8)\end{array}$ & $\begin{array}{l}-2.7 \\
(3.2)\end{array}$ \\
\hline Human capital & $\begin{array}{l}-4.1 \\
(4.6)\end{array}$ & $\begin{array}{l}-3.8 \\
(4.4)\end{array}$ & $\begin{array}{l}-3.6 \\
(4.1)\end{array}$ & $\begin{array}{l}-2.2 \\
(0.8)\end{array}$ & $\begin{array}{l}-4.2 \\
(5.4)\end{array}$ & $\begin{array}{l}-3.9 \\
(4.8)\end{array}$ & $\begin{array}{l}-4.3 \\
(6.2)\end{array}$ \\
\hline y & & $\begin{array}{l}44.4 \\
(4.3)\end{array}$ & $\begin{array}{l}37.4 \\
(3.5)\end{array}$ & $\begin{array}{l}38.7 \\
(1.2)\end{array}$ & $\begin{array}{l}33.7 \\
(4.2)\end{array}$ & $\begin{array}{l}32.2 \\
(4.0)\end{array}$ & $\begin{array}{l}41.9 \\
(4.6)\end{array}$ \\
\hline$y^{2}$ & & $\begin{array}{l}-2.9 \\
(4.7)\end{array}$ & $\begin{array}{l}-2.4 \\
(3.9)\end{array}$ & $\begin{array}{l}-2.6 \\
(1.3)\end{array}$ & $\begin{array}{l}-1.9 \\
(4.1)\end{array}$ & $\begin{array}{l}-1.9 \\
(4.1)\end{array}$ & $\begin{array}{l}-2.6 \\
(4.8)\end{array}$ \\
\hline Dummy variables & & & & & & & $\mathrm{XXX}$ \\
\hline Method & Huber & Huber & Huber & $\begin{array}{c}\text { Differences } \\
\text { between } \\
\text { countries }\end{array}$ & $\begin{array}{c}\text { Changes } \\
\text { within } \\
\text { countries }\end{array}$ & $\begin{array}{c}\text { Changes } \\
\text { within } \\
\text { countries }\end{array}$ & Huber \\
\hline $\mathrm{R}^{2}$ & 0.27 & 0.31 & 0.33 & 0.51 & 0.21 & 0.18 & 0.69 \\
\hline Number of observations & 318 & 318 & 318 & 318 & 318 & 284 & 318 \\
\hline
\end{tabular}

Source: See footnote 5 .

${ }^{10}$ For a formal derivation of these relationships, see Spilimbergo, Londoño and Székely (1999).
11 See Londoño and Székely (1998) and Birdsall and Londoño (1997). 
however (equation [4b]), these endowments have a significantly negative effect on income inequality within each country.

Thus, the simple link between trade intensity and income inequality fades if we bear in mind the effect of resource availability. The direct relationship loses its statistical significance, and trade intensity that is not due to geography, transport costs or resource availability no longer proves to have any significant link with income inequality (equation [6]).

We may therefore conclude that the supposed strong link between trade intensity and income inequality, so popular in public opinion, is not borne out by the broad database that we have today. It would therefore appear that Latin American commentators have tended to exaggerate the extent of trade openness and the strength of its link with income inequality. Although there was increased trade in Latin America in the 1990s, the increase was lower than in the rest of the world and, judging from the international results, it did not have any significant direct impact on income inequality.

Why, then, did growing economic openness in Latin America in the 1990s coincide with a level of income inequality that was higher in that decade than in the previous one? Could it be because there was a change in the relative position of the region's "resource portfolio" compared with the rest of the world?

\section{III}

\section{Changing relative resource endowments and their consequences}

In relative terms, how abundant is Latin America's resource endowment today? How has it evolved over the last decades? And what was the impact of this evolution of fundamental variables on trade intensity and income distribution?

\section{Changes in Latin America's relative resource endowment}

The region's resource availability may be measured by the monetary value of the stocks of its different assets or by physical indicators of their relative scarcity. The first route could use the study by Serageldin (1996), which values at international prices the stocks of physical and human capital and of natural resources of almost all countries of the world in the year 1990. The second route quantifies, in physical terms, the availability of unskilled labour, land, human capital and physical capital for many countries in the postwar period. Both paths illustrate the relative resource portfolio of Latin America and the way it has changed in recent decades.

Compared with the rest of the world, Latin America has a similar level of physical capital, more abundant natural resources and less human capital (figures 3 and 4). The density of unskilled labour is much greater in South Asia and China, as are the density of human

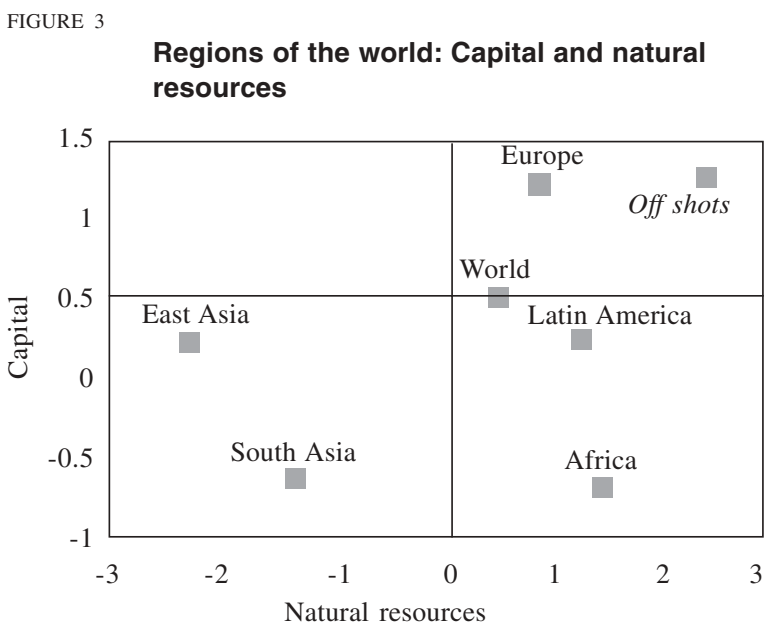

Source: See footnote 5 on page 28.

capital in East Asia and Eastern Europe and the density of natural resources in the Asian States that were formerly part of the Soviet Union's sphere of influence.

Paradoxically, however, Latin America now has the aggregate mix of resources most similar to the average for the world. Although regions with a similar resource endowment -such as the European Union- can increase their trade through economic policy decisions, the fact is that relative lack of specialization in some factors 
FIGURE 4

Regions of the world: Human capital and natural resources

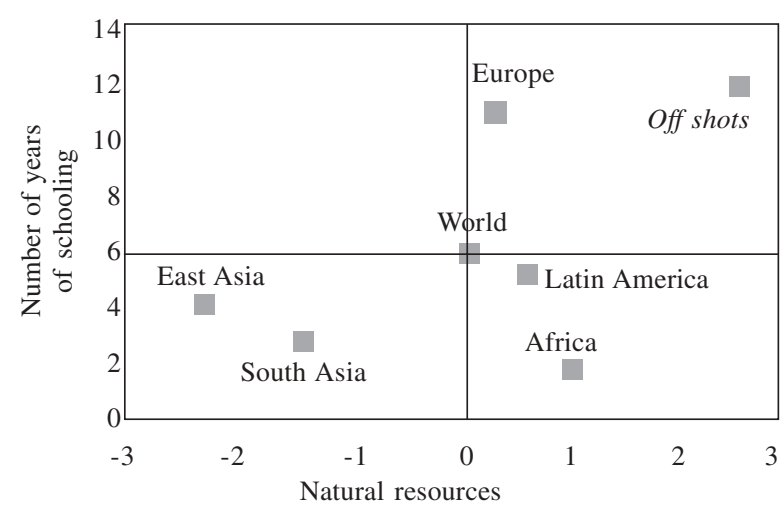

Source: See footnote 5 on page 28 .

compared with the rest of the world does not, according to the Ricardian tradition, favour greater trade intensity.

The resource portfolio is not a historical constant, since it is the result of the expansion of primary factors and the relative accumulation of physical and human capital in different countries: a dynamic which is influenced by political decisions with respect to patterns of specialization and development strategies. This is why it has changed. Up to the mid-1970s, Latin America had a relative abundance of land and unskilled labour, as well as a decreasing relative density of capital per worker (figure 5). This situation has changed radically over the last twenty years, however. The entry into the
FIGURE 5

Latin America: Resource portfolio, 1960-1995

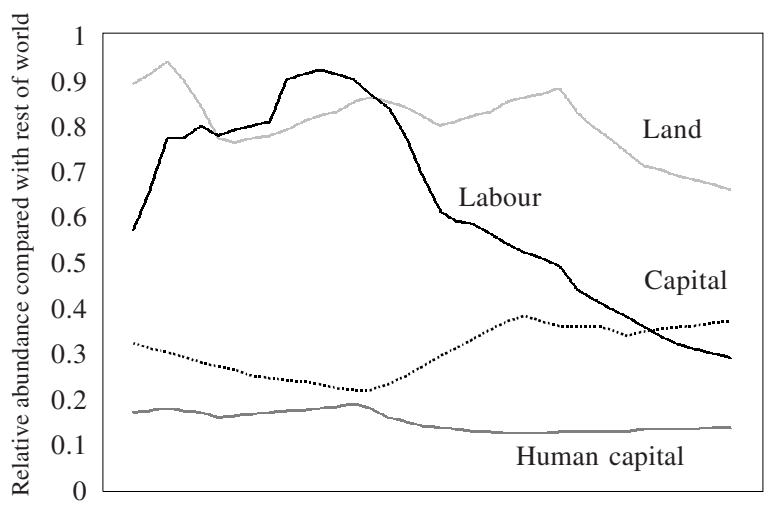

Source: See footnote 5 on page 28.

world trade arena of regions as vastly different in terms of resource endowment as Asia, China and Russia revealed that the absolute abundance of primary resources which had always characterized Latin America in the past was no longer a relative abundance compared with the rest of the world.

Thus, it was the evolution of the other regions of the world that changed the relative abundance of the factors that can be accumulated in Latin America. As from the 1970s, the developed countries increased their relative density of physical capital much faster than Latin America, while the other developing countries -especially those of Asia- accumulated more human capital than the Latin American region (table 4).

TABLE 4

Selected regions: Changes in relative resource endowment

\begin{tabular}{lccccccc}
\hline & $1960-1965$ & $1966-1970$ & $1970-1974$ & $1975-1979$ & $1980-1984$ & $1985-1989$ & $1990-1995$ \\
\hline OECD & & & & & & & \\
$\quad$ Capital & 4.68 & 4.72 & 4.76 & 4.80 & 4.84 & 4.88 & 4.92 \\
$\quad$ Education & 4.76 & 4.79 & 4.82 & 4.85 & 4.88 & 4.91 & 4.94 \\
$\quad$ Land & 3.60 & 3.65 & 3.70 & 3.75 & 3.80 & 3.85 & 3.60 \\
$\quad$ Labour & 0.32 & 0.33 & 0.34 & 0.35 & 0.36 & 0.37 & 0.38 \\
& & & & & & & \\
Developing countries & 0.07 & 0.08 & 0.08 & 0.08 & 0.08 & 0.09 & 0.09 \\
$\quad$ Capital & 0.19 & 0.20 & 0.20 & 0.21 & 0.21 & 0.22 & 0.23 \\
$\quad$ Education & 0.28 & 0.28 & 0.28 & 0.28 & 0.28 & 0.28 & 0.29 \\
$\quad$ Land & 0.66 & 0.68 & 0.70 & 0.73 & 0.75 & 0.78 & 0.80 \\
$\quad$ Labour & & & & & & & \\
Southeast Asia & & & & & & & \\
$\quad$ Capital & 0.04 & 0.05 & 0.05 & 0.06 & 0.06 & 0.07 & 0.08 \\
$\quad$ Education & 0.67 & 0.70 & 0.73 & 0.74 & 0.75 & 0.76 & 0.77 \\
$\quad$ Land & 0.06 & 0.06 & 0.06 & 0.07 & 0.07 & 0.07 & 0.07 \\
$\quad$ Labour & 0.28 & 0.32 & 0.36 & 0.40 & 0.44 & 4.48 & 0.52 \\
\hline
\end{tabular}

Source: See footnote 5 on page 28 . 
Latin America lost relative primary resource abundance, but it did not gain physical or human capital abundance. This trend contrasts sharply with the abundance displayed by the East Asian countries, where capital endowment per worker increased tenfold and education moved from a low level (half of the world average) to a high level (double the world average).

\section{The effects of the changes in resource endowment}

If relative resource abundance is of key importance for trade intensity and income inequality, and if relative resource endowment in the world has changed so much, how strong was the quantitative impact of the changing relative resource abundance on trade and equity in Latin America? To answer this question, we conducted a simulation exercise, applying the parameters of the best equations to the evolution of an average Latin American country, calculated as the arithmetic average of 19 countries.

a) Did Latin American openness really increase all that rapidly?

According to the changes in economic geography, transport costs and resource abundance, the trade intensity of Latin America (equation [8] of table 2) should have started to increase as from the 1960s. In view of this expectation, the increase in openness observed in the region does not seem very remarkable, since it rose from 54 in that decade to 65 in the 1970s and subsequently 70 in the 1990s. Indeed, the openingup was slower than would have been suggested by international experience. For that reason, paradoxically and in spite of the increase in openness actually registered, the disparity between the level of trade observed and that which could have been expected in view of the intensity of world trade became increasingly wide, even in the 1980s.

The persistent lag in Latin America's trade intensity is attributable to the evolution of its resource portfolio rather than to its foreign trade policies. According to world trade trends, in the last three decades Latin America should have displayed constantly growing trade intensity (figure 6). The relative changes in its resource endowment had the opposite effect, however. Up to the early 1970s, the greater relative abundance of its primary resources -land and labour-accelerated trade, but subsequently the changes in its resource portfolio were not favourable to more intensive trade, and indeed its lesser relative primary resource
FIGURE 6

Changes in trade intensity attributable to changes in resource portfolio, 1960-1964 to $1990-1994$

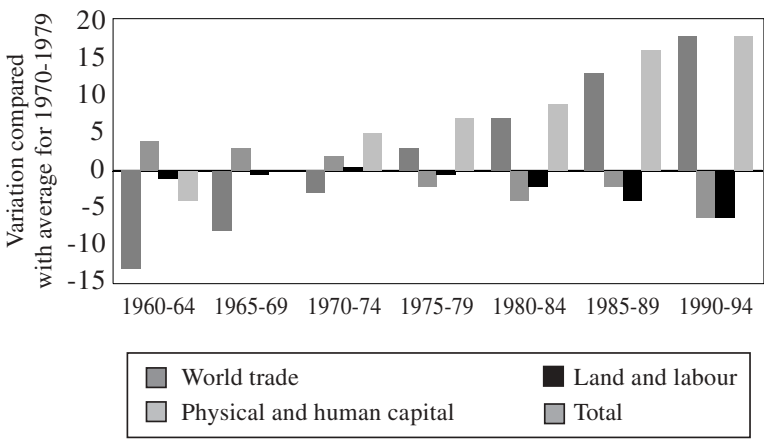

Source: See footnote 5 on page 28 .

abundance and lesser relative accumulation of physical and especially human capital resulted in a slackening in trade intensity.

\section{b) The impact on income distribution}

The Gini coefficient of income inequality for the region as a whole, calculated by Londoño and Székely (1998), indicates that in the last three decades inequality has persisted, albeit with considerable short-term fluctuations and a marked increase since the mid-1980s (figure 7).

Latin America has a similar resource portfolio to the world average but much greater income inequality, which may be accounted for by the greater inequality in the distribution of land, capital and also education. Given the difference in levels of inequality associated with the resource ownership structure, and making allowances for short-term effects linked to macroeconomic trends, ${ }^{12}$ the medium-term inequality trend can be broken down according to the changes in the fundamental variables.

How should income inequality have evolved in view of the changes in magnitude and in the economic resource portfolio? According to the Kuznetsian approach, in the 1950s Latin America had already passed the point of maximum inequality, and inequality should be on the decline, with a temporary interruption in the 1980s (equation [1c] of table 1). The evolution of the resource portfolio modified these simple

\footnotetext{
12 These are analysed in Londoño and Székely (1998); Morley (2001); Ganuza and others (eds.) (2001), and Stallings and Peres (2000).
} 
FIGURE 7

Latin America: Income inequality

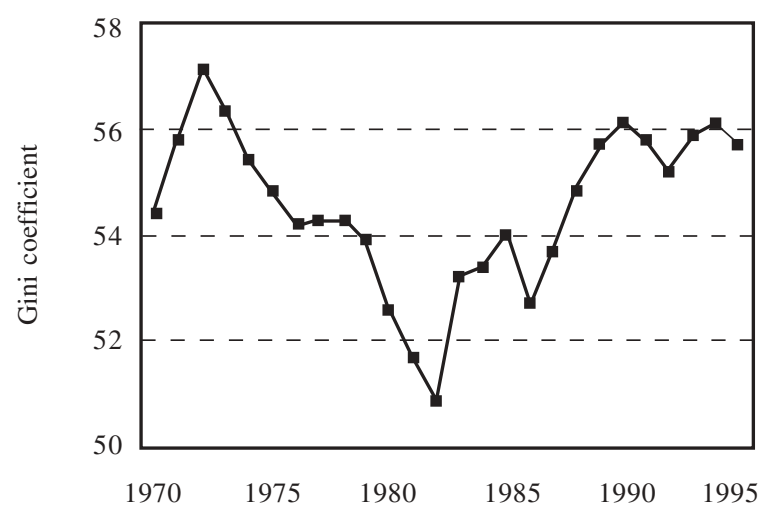

Source: See footnote 5 on page 28.

predictions and, according to equation [2] of table 3, postponed the turning point in terms of inequality to the late 1980s. Thus, economic growth in a context of changes in the resource portfolio should have led to high and persistent inequality. Although its volatility was in fact higher, this was precisely the trend in the Gini coefficient during the period in question (figure 8).

As Kuznetsian income has very little quantitative impact, the main impact in terms of distribution came from the changing relative resource abundance. The lower relative abundance of primary resources such as land and labour would have tended to reduce the Gini coefficient from the mid-1970s on, while the slow accumulation of human and physical capital from the end of that decade would have generated, on the other hand, a more than proportional increase in income inequality (figure 9).

Thus, underlying the apparent medium-term inertia and short-term volatility of the aggregate indicators of inequality there are significant changes in the

\section{IV}

\section{Conclusions}

Some analysts have linked the deterioration in distribution that followed the debt crisis of the early 1980 s to the extent and speed of the structural reforms undertaken to stabilize and open up the economies of the region. The literature on this issue is still debating the effects that macroeconomic factors have had on
FIGURE 8

Latin America: Contrast between observed and expected levels of income inequality, 1965-1969 to 1990-1994

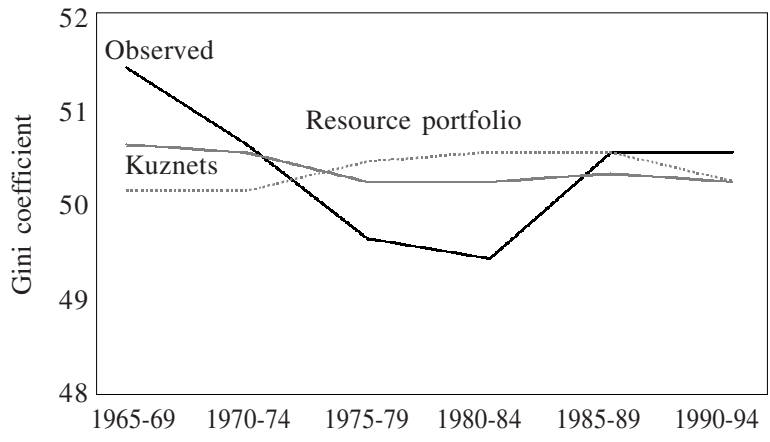

Source: See footnote 5 on page 28.

FIGURE 9

Latin America: Factors of change in income distribution, 1965-1969 to 1990-1994

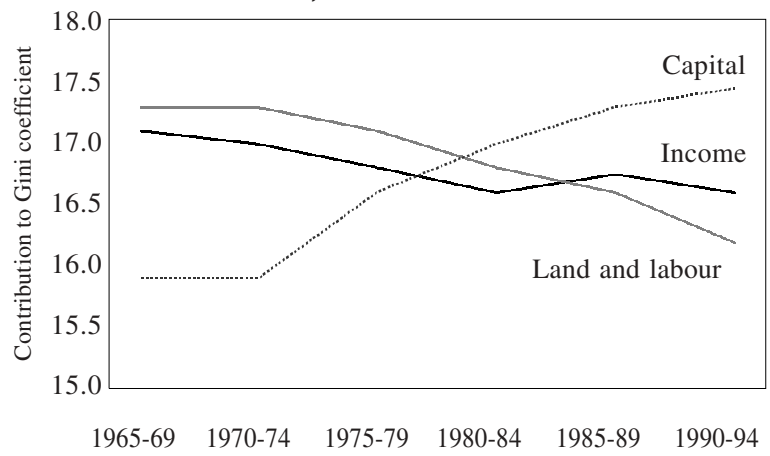

Source: See footnote 5 on page 28 .

continent's distributive patterns. The relative incomes of the different population groups have varied enormously with changes in the resource portfolio of Latin America and the rest of the world. inequality in the last two decades. Bulmer-Thomas (1996) and Berry (ed., 1998) see negative effects, while Londoño and Székely (1998) see them as positive and Stallings and Peres (2000) and Ganuza and others (eds., 2001) see them as ambiguous and different in different countries. 
This study goes one step further and concludes that the lack of distributive progress in Latin America is associated not so much with the speed of the process of opening up as with the slowness of the process of capital accumulation (both physical and, above all, human) at times of huge shifts in relative abundance in other regions of the world.

In fact, Latin America's generation of new trade since the 1980s has not been very fast, and its direct effects on income inequality are negligible.

In reality, the common causal factor underlying the changes in trade intensity and income inequality is the resource portfolio. The particular way in which Latin America's relative resource abundances evolved in comparison with the rest of the world gave rise to a paradox. In the 1950s and 1960s, the growing relative abundance of its primary resources simultaneously increased trade and inequality, but from the 1970s on the massive entry of the other developing countries into world trade shifted this relative abundance of primary resources, reducing both the opportunities for trade and the tendencies towards greater income inequality. In the last twenty years, throughout the world, the new opportunities for increasing trade, growth and equity have stemmed from greater physical and human capital, but this occurred just when (in the 1980s and 1990s) the region fell behind in its capital accumulation, with unexpected consequences.
The 1990s were years of structural reforms in Latin America. The main efforts were directed at stabilizing the fiscal accounts and eliminating trade barriers. Future progress in terms of income distribution and effective trade intensity (going lontano) will depend above all, however, on the advances in production which would go hand in hand with a faster rate of accumulation of physical and human capital. The slow progress in that direction in the last few decades (chi va piano...) has proved very expensive for the region in terms of equity and trade with the rest of the world.

In the decade from 2000 on, the focus of structural policies should shift away from trade liberalization towards the protection of investment by stimulating and fostering a propitious climate for it. If the Free Trade Area of the Americas (FTAA) is not accompanied by a substantial boost for corporate investment, it may prove to be an instrument with little impact on income distribution.

In the new century, the objective should be not just to speed up capital accumulation, but to do so at a faster pace than the rest of the world. If it is to overcome the risk of isolation, inequity and poverty, Latin America has no alternative but to protect corporate and household investment and move fast ... faster than the tigers.

(Original: Spanish)

APPENDIX

The theoretical framework used

This appendix presents theoretical elements on the relationships between income distribution, production factor prices and distribution of ownership. It first of all reviews a model for a small open economy and from this perspective then goes on to examine a world composed of different economies that have the same production function and preferences but differ in terms of production factor endowments. After this, it considers the implications of trade for income distribution.

\section{A small open economy}

In a small open economy, the international price vector, $\mathrm{P} *$, determines the internal prices of tradeable goods. International trade can also determine the price of factors under the following conditions: a) the economy is very similar to the rest of the world in terms of factor endowment; b) this economy has the same technology as that of the rest of the world; c) there are no non-tradeable goods; d) there are at least as many goods as factors; e) production functions are homogeneous of degree one, and f) there are no break points in factor intensity. If the above conditions are satisfied, an equation can be established in which internal factor prices are determined by the international prices of goods:

$$
W^{0}=W\left(P^{*}\right)
$$

If, in any of the conditions listed above, this relation fails to apply, then internal factor prices are determined by the international prices of goods, $\mathrm{P}^{*}$, and the internal factor endowment, E:

$$
W^{0}=W\left(P^{*}, E\right)
$$

In an integrated world economy where the factor endowments of individual countries do not differ too much, international prices are determined by the world relative resource endowment in the same way as in a closed economy (Dixit and Norman, 1980):

$$
P^{*}=P^{*}\left(E^{*}\right)
$$

Substituting equation 3 in equations 1 and 2 yields:

$$
W^{0}=W^{0}\left(E^{*}\right) \text { and } W^{0}\left(E^{*}, E\right)
$$

These equations show that the factor prices are determined by the international endowments when conditions 
(a), (b), (c), (d), (e) and (f) hold good, and also by internal factor endowments under more general conditions.

The case illustrated here is only for reference and is not realistic, because most of the economies in the world have tariffs. When governments intervene and impose tariffs and other barriers, equation [1] is not fulfilled, and in equation [4] there is a distortion, which we will call $T$, so that:

$$
W^{0}=W^{0}\left(T, E^{*}, E\right)
$$

\section{Income distribution}

In the foregoing section we identified the determinants of factor prices, factor income distribution and the openness of an economy. The link between factor income distribution and personal income distribution is given by the ownership structure. Each individual may obtain his income from several factors of production, so that the total income of an individual $i, y_{i}$, is the sum of the income from all sources:

$$
\begin{gathered}
y_{i}=w_{i}\left(E, E^{*}, T\right) E_{l} \omega_{i 1}+\ldots \\
w_{j}\left(E, E^{*}, T\right) E_{j} \omega_{i j} \quad \text { with } \quad i=1, \ldots, I
\end{gathered}
$$

where $E j$ is the endowment of factor $\mathrm{j}$ in the economy, and $d_{i 1}$ is the share of individual $i$ in ownership of factor 1 .

By construction, $\sum_{I}^{i=1} \omega_{i j}=1$ for $j=1, \ldots \ldots, J . w_{j}$ represents the payment to factor $j$, and we will call $\Omega$ the matrix of coefficients $\omega_{i j}$ which describes the ownership structure.

An indicator of income distribution like the Gini coefficient is a function of the income of each of the individuals:

$$
\text { Gini } \equiv g(Y)=g\left(E, E^{*}, T, \Omega\right)
$$

We will use this last equation as the basis for our empirical research. It indicates that personal income distribution depends on the same variables which determine the factor income distribution, and on the ownership structure $\Omega$

The matrix $\Omega$ is determined by historical conditions and may differ greatly between countries. The variations over time in each country are expressed through $\Omega$. Some factors of production, such as land and capital, may be concentrated in the hands of a few people because there is no natural limit to their accumulation, but other factors of production, such as knowledge, cannot be concentrated so much, because there are natural limits to the amount of education that an individual can accumulate. This observation places a limit on the variation of $\omega_{i j} E_{j}$ if the resource $j$ is human capital. Consequently, if an economy is endowed for the most part with land and physical capital, there is no limit to the concentration of wealth, but if an economy's principal endowment is education, income distribution should be more equal, providing the other factors remain constant.

\section{Bibliography}

Acemoglu, D., S. Johnson and J. Robinson (2001): Reversal of Fortune: Geography and Institutions in the Making of the Modern World Income Distribution, NBER working paper, No. 8460, Cambridge, Massachusetts, National Bureau of Economic Research (NBER).

Barro, R. and J. Lee (2000): International Data on Educational Attainment: Updates and Implications, CID working paper, No. 42, Boston, Harvard University, Center for International Development (CID).

Berry, A. (ed.) (1998): Poverty, Economic Reform and Income Distribution in Latin America, Boulder, Colorado, Lynne Rienner.

Birdsall, N. and J. L. Londoño (1997): Asset inequality matters: An assessment of the World Bank's approach to poverty reduction, American Economic Review, vol. 87, No. 2, Nashville, Tennessee, American Economic Association.

Bourguignon, F. and C. Morrison (eds.) (1990): Income distribution, development and foreign trade, European Economic Review, vol. 34 .

Bulmer-Thomas, V. (1996): The new economic model in Latin America and its impact on income distribution and poverty, London, University of London, mimeo.

Cohen, D. (2001): Fear of globalization: The human capital nexus, World Bank, Proceedings of the $13^{\text {th }}$ ABCDE World Bank Conference, Washington, D.C.

Deininger, K. and L. Squire (1996): Measuring income inequality: A new data base, The World Bank Observer, Washington, D.C., World Bank.

Dixit, A. and V. Norman (1980): Theory of International Trade, Cambridge, United Kingdom, Cambridge University Press.
ECLAC (Economic Commission for Latin America and the Caribbean): Social Panorama for Latin America, Santiago, Chile.

(2000): Equity, development and citizenship, LC/G.2071, Santiago, Chile.

Edwards, S. (1997): Trade policy, growth and income distribution, American Economic Review, vol. 87, No. 2, Nashville, Tennessee, American Economic Association.

Engerman, S. and K. Sokoloff (1997): Factor endowments, institutions, and differential paths of growth among new world economies: A view from economic historians of the United States, in S. Haber (ed.), How Latin America Fell Behind: Essays on the Economic History of Brazil and Mexico, 18001914, Stanford, Stanford University Press.

Gallup, J., J. Sachs and A. Mellinger (1998): Geography and Economic Development, NBER working paper, No. 6849, Cambridge, Massachusetts, National Bureau of Economic Research (NBER).

Ganuza, E. and others (eds.) (2001): Liberalización, desigualdad y pobreza: America Latina y el Caribe en los '90, Santiago, Chile, United Nations Development Programme (UNDP).

IDB (Inter-American Development Bank) (2000): Facing Up to Inequality. Annual Economic Report, Washington, D.C.

Krugman, P. (1992): Geography and Trade, Cambridge, Massachusetts, MIT Press.

Leamer, E. (1987): Paths of development in the three-factor, n-good general equilibrium model, Journal of Political Economy, vol. 95, No. 5, Chicago, Illinois, The University of Chicago.

Leamer, E. and others (1999): Does natural resource abundance increase Latin American income inequality?, Journal of 
Development Economics, vol. 59, No. 3, Amsterdam, Netherlands, Elsevier Science Publishers, B.V.

Lindert, P. and J. Williamson (2001): Does Globalization Make the World More Unequal?, NBER working paper, No. 8228, Cambridge, Massachusetts.

Londoño, J. L. and M. Székely (1998): Sorpresas distributivas después de una década de reformas, Pensamiento iberoamericano, special issue, Madrid, Agencia Española de Cooperación International.

Madisson, A. (1996): Monitoring the World Economy, Paris, Organization for Economic Cooperation and Development (OECD).

Morley, S. (2001): The Income Distribution Problem in Latin America and the Caribbean, LC/G.2127-P, Santiago, Chile, ECLAC.

Ocampo, J. A., R. Bajraj and J. Martin (coords.) (2001): Una decada de luces y sombras: América Latina y el Caribe en los años noventa, Santiago, Chile, ECLAC.

O'Rourke, K. (2001): Globalization and inequality: Historical trends, World Bank, Proceedings of the 13th ABCDE World Bank Conference, Washington, D.C.

O'Rourke, K. and J. Williamson (2002): From Malthus to Ohlin: Trade, Growth and Distribution since 1500, NBER working paper, No. 8955, Cambridge, Massachusetts, National Bureau of Economic Research (NBER).

Penn World Tables (1995): Cambridge, Massachusetts, National Bureau of Economic Research (NBER), www.nber.org
Robbins, D. (1996): HOS hits facts: facts win. Evidence on trade and wages in the developing world, Discussion paper, No. 557, Boston, Harvard Institute for International Development.

Sachs, J. (2002): Tropical Underdevelopment, NBER working paper, No. 8119, Cambridge Massachusetts, NBER.

Serageldin, I. (1996): Sustainability and the Wealth of Nations: First Steps in an Ongoing Journey, "Environmentally sustainable studies and monograph series", No. 5, Washington, D.C., World Bank.

Spilimbergo, A., J. L. Londoño and M. Székely (1999): Income distribution, factor endowments and trade openness, Journal of Economic Development, No. 59, The Economic Research Institute.

Stallings, B. and W. Peres (2000): Crecimiento, empleo y equidad: el impacto de las reformas en América Latina y el Caribe, Santiago, Chile, Fondo de Cultura Económica/ ECLAC.

Williamson, J. (1996): Globalization and Inequality: Past and Present, NBER working paper, No. 5491, Cambridge, Massachusetts, NBER.

Wood, A. (1997): Openness and wage inequality in developing countries: The Latin American challenge to East Asian conventional wisdom, The World Bank Economic Review, vol. 11, No. 1, Washington, D.C., World Bank.

World Bank (several issues): World Bank Tables, Washington, D.C. 